\title{
Structure and Features of Politically-Invested Hoaxes
}

\author{
Kamaludin Yusra* \\ English Department \\ Universitas Mataram \\ Mataram, Indonesia \\ kamaludin@unram.ac.id \\ Nuriadi Nuriadi \\ English Department \\ Universitas Mataram \\ Mataram, Indonesia
}

\author{
Amrullah Amrullah \\ English Department \\ Universitas Mataram \\ Mataram, Indonesia
}

Yuni Budi Lestari

English Department

Universitas Mataram

Mataram, Indonesia

\begin{abstract}
Hoaxes and their spread in social media have led various politicians led to legal issues and a few of them have born legal jail or financial consequences due to hoaxes and other fake news. These should have been avoidable if the fake news makers have understood two essential points. Firstly, understanding and loyalty to politically correct communication when communicating in public evading ethnic, religion, race, inter-group, and sexual orientation of the communication partners. Secondly, understanding the textual and linguistic features of fake news and refraining themselves from spreading them becomes essential. Theoretically, every text produced and reproduced by the news makers serve certain social functions, textual structures, and linguistic features. Functionally, hoax news is produced and reproduced for the purpose of spreading incorrect and untrue information about certain political issues so that readers change their mind or political affiliation. Such political agenda are textually engineered within the textual structure which is in turn realized within certain types of sentences, clauses, phrases, and words.
\end{abstract}

Keywords - fake news, social function, textual structure, language features,

\section{INTRODUCTION}

Lately, there have been complaints about negative news spread in the mainstream and the social media. The mainstream media such as television, radio, and other mass media were oftentimes complained to because of imbalanced or one-sided news therein. The sources of information were from one side and other parties involved were not taken into account although they might provide the other sides of the story. In addition, the media constructed the supported side to be true and the other parties were created and recreated as if they were wrong. Although required to be balanced, numerous readers criticized them of trial by the press. Though having rights to reply, the unbenefited parties were often unprovided with such rights and they were left with the guilty sense.

In the social media, the spread of fake news or hoaxes has become more intensive either in the forms of fake news about ethnic groups, race, religion and persons.
When there is negative news about persons of particular ethnic backgrounds, the ethnic groups rather than the persons were blamed responsible for the negative action and, consequently, negative news about the ethnic groups become wide spread. This is one form of political incorrectness where social groups are blamed for the action of their members and such incorrectness are performed by formal news broadcasters and individual persons. For example, when news about illegal immigrant workers from particular races and ethnic groups were circulated, negative news and information about the race and ethnic groups are also present within or after the news. Not only found at the topics, the introduction and the contents of the news, the blames could be found in the comments made by news consumers in the comment columns. The negative information was literally expressed but also metaphorically implied in the symbolic meanings of words, phrases, and sentences, or comments. The blame strategies can also be found in discourses involving netizens of different religion, profession or social backgrounds.

The debates will be even sharpened when hoaxes or fake news involving political needs, parties, and supports in the 2019 Indonesian presidential election. The contrast between Islamic and non-Islamic supporters has led to the emergence of positive and negative news about both groups found in local printed and online newspapers and in groups, organization, and personal blogs. The supporters of nationalism created news about the excellence of nationalism and nationalistic parties and the drawbacks of anti-nationalism and its supporting parties. Supporters of Islamism spread news about the need to return to Islamic points of view implemented through Islamic parties. Supporters of a party will instigate the excellence of the party and expose the weakness of others. Other parties will do likewise. These are often found not only in the party's online platforms but also in the statuses, comments, memes, and instagrams made by the supporters.

Production and reproduction of hoaxes and fake news on social media were intensified during the 2019 election campaigns. Although diversified in numerous parties and legislative aspirations, social media users have already been divided into two groups: the tadpoles or the frogs and 
the bats or the desert lizards. Accepted or not, the tadpoles or frogs are defined based on their supports to the then running president and his mate (Joko Widodo \& Makruf Amin) and assumed to support parties supporting them. For political correctness, this group is labeled Projo. The bats or the lizards, on the contrary, refer to those opposing Projo and associated themselves with Prabowo Subiyanto and Sandiaga Salahuddin Uno as presidential candidates and parties supporting them. Each group has been accused of producing and reproducing fake news about each other. Each group has had hoax-related legal cases due to unknowingly spreading fake news. A few netizens have been put to jails and these should have been avoided if they could identify the nature of fake news.

The best strategy to evade from producing and reproducing hoaxes and its legal traps is by identifying the textual structure and language feature of fake news. Theoretically, news as a text is produced and reproduced within the contexts of political cultures and the contexts of the 2019 legislative and presidential election situations. Thus, the social function of the political news and texts is to persuade the readers to opt for the author's political aspiration and, for this purpose, the news presented could be true, half true, false or counter-factual. Unfortunately, readers are affected by the fake news and reproduce it in their networks. Others unknowingly spreading the fake news might be trapped in legal cases. While truth about the contents of political news depends very much on the world knowledge of the netizens, this knowledge often comes much later. Thus, the best solution is by identifying the textual characteristics of fake news, but, unfortunately, the textual structure and the language features of fake news have not been identified. This is the merit of the current study

Language has been the main means of human verbal communication. ${ }^{[1]}$ Though the use of nonverbal symbols is common in real and digital worlds, verbal communication has been the main mode of interaction. In communication, verbal and nonverbal signs have meanings. In verbal communication, sounds are combined into words, phrases, sentences and texts in order to convey intended messages. As a carrier of messages, language is neutral by bringing meanings no more or less borne in the messages. ${ }^{[2]}$ Nonetheless, when the mood of expression is inappropriate, it is no longer neutral. When expressed in high-tone anger mood, the message becomes irritating. Conversely, when the message is unpleasant but conveyed in pleasant mood, it then becomes pleasing to the receivers.

In political communication, the relationship between the government and the people is often seen as power relation. The governments being powerful use bureaucratic languages to maintain the superiority. ${ }^{[3]}$ For an instance, admission of guilt will not be made personal but rather institutional even when the guilt is personal.

Language in political communication usually represents the voice of bureaucrat and businessmen ${ }^{[4]}$. This can be seen in the languages of the bureaucracy and the media. In the media, news is structured in such a way that those with political power become newsmakers while the politically marginalized are victimized. In fact, news as a discourse practice has its own context socially coconstructed between the reporter, the media and the news objects. In it, there is a process where experience and interaction between them are represented. Nonetheless, news as a mode of communication is undetectable from political needs and affiliation with particular political groups.

Language and political communication can be linked with the thought of Ludwig Witgenstein where political communication is seen as a language game and power and exercise of power are contested. Language is no longer seen as a mode of communication but rather a site where political games are contested and winers-loosers are determined. ${ }^{[5]}$. As a site for political game, language plays an essential role in the game because political actors participating in the game should act in such a way so that the audience buy into their ideas. ${ }^{[6]}$ Consequently, language is no longer seen as a neutral site ${ }^{[7]}$ and choices of words, sentences and tones of voices represent ideology, political orientation, hegemony or counter-hegemony of the users and, thus, language use is associated with conflicts where attacks and counter-attacks, hegemony and counter hegemony are in action and language is the only weapon. The winner is determined not based on truthful facts $^{[5]}$, but rather on empirical illusion on the winner within the state of the affair ${ }^{[7]}$.

As a weapon, language should be constructed in text formats ${ }^{[8]}$. Texts are actually the sites where communicative games are played. Texts are basic units of semantic, semiotic and political processes where potential meanings are actualized and these meanings are referred to as social functions, that is, social roles the texts play within human communicative games. Every text play a culturally ideological role in the society and without it the society does not have ideology that texts play within the society ${ }^{[9]}$. In mediated political discourses, the ideological roles are often played by hoaxed or fake news in order to strengthen or change political choices.

The socio-political roles are realized in particular structures $^{[8]}$. These structrues are known as the generic structure, representing social systems and structures of the users. Different structures play different roles. Though difficult, identifying these structures is essential and this could be done by teasing out the potential textual structure $^{[10]}$. The smallest units within the structures are sentences with particular characteristics and these are referred to as language features ${ }^{[10][11]}$. The language features have the power of constructing contexts within which meanings are created and interpreted ${ }^{[12]}$ and without these features the texts will fail in their roles. Unfamiliar changes in the structures and features of particular texts might indicate the existence of new contexts untruthful, hoaxed, or deviant to the original ones ${ }^{[13]}$.

Though other text types have been widely analysed, political hoaxes and other fake news have not been largely known. Some studies have shown that false information news as a type of hoax news has typical language features that help the news go viral. The information is neither transparent nor auditable that crosschecking it with other sources is essential ${ }^{[14]}$. Other studies require the readers examine the identities of the authors and, when 
unidentifiable, their styles of writing before deciding to digitally share information ${ }^{13}$. Others claim that fake news has been faked by-design in its layout, structure, and language features so as to manipulate the readers' cognition ${ }^{15,16}$ and follow the author's train of thought.

In the current study, political hoax news and real news was analyzed from various dimensions in order to tease out the functions, textual structures, and language features of political hoaxes.

\section{METHOD}

The study is discursive with descriptive approach. The social function, textual structures and language features of political hoaxes were analysed. The foci were all political hoaxes produced and reproduced in the social media and the sample was selected by using proportional dimensional purposive sampling technique. The data were ethnographically collected with participatory mode of collection and verbal data were downloaded, transcribed, and coded for discursive analyses.

\section{RESULTS AND FINDINGS}

The main results of the study were types, structures, and language features of political hoaxes.

\section{A. Types of Political Hoaxes}

Out of 1695 political hoaxes collected, eight types of political hoaxes were identifiable: false context (23\%), imposter broadcasters (20\%), fake sites (15\%), false information (14\%), manipulative content (14\%), false connection (8\%), and parody-satire content (8\%). These findings are in line with those in other studies. A study of political hoaxes during US presidential election reported six types of hoaxes: false context or authentic material used in the wrong context, imposter news sites designed to look like brands we already know, fake news sites, fake information, manipulated content, and satire or parody content[17]. This finding is in line with those findings in the other studies. Unavailable in the study were imposter broadcasters and false connection.

\section{B. Functions of Political Hoaxes}

Pragmatically, political hoaxes serve the following functions: self-promotion (27\%), black campaign on opponents (20\%), collecting larger readership (16\%), rebuttaling information from opponents (14\%), spreading positive information about own political groups $(8 \%)$, countering negative information spred by opponents (8\%), and reaffirming accusations to opponents (8\%). These functions were also shared in the study of hoaxes in the US presidential election where information and its sources were manipulated in order to gain political and financial benefits[18] in favour of the paying political groups or through advertisements and sale of products accrued from the spread of the hoaxes.

\section{Textual Structure of Political Hoaxes}

Fake news, political or not, has its own structure as its main purpose is to manipulate the readers textually and cognitively. Political hoaxes have systemic features identifiable from the sources and the channels that they use. Each competing political group has its own online media supporters promoting them and derogating the opponents. Netizens or readers, nonetheless, cannot always identify the connection. Thus, identifying the structure and features become essential.

In interactive social media (memes or statuses in FB, twitter or instagram), political hoaxes are constructed in this order: Goal^Accusation, or $\mathrm{Goal}^{\wedge}$ Affirmation, or $\mathrm{Goal}^{\wedge}$ Accusation ${ }^{\wedge}$ Affirmation. Goal comes in the form of positive expressions and praises to own group or accusation to opponents. The opposite is accusation or reference to accusation made by the opponents with or without supporting evidence. Affirmation is restatement of the goal with the same or different wording.

In written texts, political hoaxes appear in the following structure: Goal^Author ${ }^{\wedge}$ Orientation^ ${ }^{\wedge} \mathrm{Re}$ Orientation ${ }^{\wedge}$ Accussation ${ }^{\wedge}$ Evid-ence ${ }^{\wedge}$ Affirmation.

Orientation and reorientation respectively introduce the readers with negative issues about the opponents and, with fake facts, mislead them into believing that the author is right and the opponents are wrong.

\section{Language Features of Political Hoaxes}

Political hoaxes particularly the false- information type have specifically designed features to go viral[14] and, therefore, transparency, auditability, and credibility of the information and its source must be checked before deciding to share it[13]. Fake news is by-design falsified[15] in its layout, textual structure, and language features in order to manipulate the readers' cognition[16]. This study finds the above textual structure with specific language features.

Political hoaxes have found several language features. These features can be used to measure the accuracy of the news.[19] Studying these features, researchers should combine linguistic stylometric analysis and computeristic analysis with deep learning algorithm[13] and this combined analysis can accurately redict the actual author(s) of hoaxes with $96.6 \%$ accuracy. However, the higher the level of deception in news the more subtle the deception is and the more difficult it is to be detected[19] as hoaxes.

The current study finds that political hoaxes have the following features. Goal is explicated in highly-convincing words. Author uses fake or falsified names. Orientation is presented in a series of events or facts so that readers have no chance to question the truth value of each statement. Reorientation is marked by indirect styles either by questioning or by reporting other sources of information. Accusation is expressed either in highly-convincing, tentative, direct or indirect sentences. Evidence is provided in balance by quoting opponent's proposition, by using conditional sentences, by emphasizing the opponent's disability to be responsible or being responsible to cases, by playing victims, by misleadingly quoting the words of the opponents to own benefits, or by requiting the opponents to reaffirm their weaknesses. Affirmation of accusation is marked by excessively strengthening the accusation, by restating or resummarizing the goal, or by quoting references in support or denial of accusation.

Just like findings in other studies,[13][14][15][17][19] the current study also finds that political hoaxes are identifiable in terms of quantity of words (use more words, 
multi-syllable words, and long sentences), complexity of sentences (high frequency of complex sentences), high degree of certainty (more modals of certainty than probability), high degree of subjectivity (more subjective and affective adjectives and adverbs), and close relationship between the author and the audience through the use of solidary pronouns and power pronouns.[20] In general, the study shows that political hoaxes have lower quality of language in terms of politeness and formality and deny moral values highlighted in Indonesian cultures.[21][22]

It appears that political hoaxes were constantly from particular groups and it is thus fair to assume that the spread of them was funded by associated parties. These were also found in India [23] or in America [24] that political hoaxes are financially driven.[25]

\section{CONCLUSION}

The study has found seven types of political hoaxes and explicated the textual structures and linguistic features of the generic structures. These show that political hoaxes have been structurally designed with misleading information and the authors have linguistically crafted the information with convincing language in order to manipulate and reshape the readers' beliefs.

\section{REFERENCES}

[1] Halliday, M. A. K. 1993. "Language as Social Semiotic." Janet Maybin (Ed.) Language and Literacy in Social Practice: A Reader: Clevedon: Multilingual Matters, pp. 23-43.

[2] Heryanto, Ariel. 1989. Berjangkitnya Bangsa-Bangsa di Indonesia. Majalah Pemikiran Sosial Ekonomi. Prisma No 1 Tahun XVIII, 1989. pp 3-16, LP3ES.

[3] Lubis, Muhtar. 1989. Media Massa dan Bahasa yang Terus Terang. Majalah Pemikiran Sosial Ekonomi. Prisma. No 1. Tahun XVIII. 1989. pp 47-51. LP3ES.

[4] Kurniawan, R. Okta. 2003. Bahasa: Sebuah Kekuatan. Warta Departemen Pertahanan Republik Indonesia. Volume 15 No 1 Mei-Juni 2003. Biro Humas Setjen Dephan, Jakarta.

[5] Wilujeng, Sri Rahayu. (2003). Bahasa Politik dalam Perspektif Filsafat Bahasa Ludwig Wittgenstein. https://media.neliti. com/media/publications/5029-ID-bahasa-politik-dalam-perspektiffilsafat-bahasa-ludwig-wittgenstein.pdf. Diakses 12 Pebruari 2019 pukul 19.00 WITA.

[6] Bertens, Kees. 1983. Filsafat Barat Abad XX: Inggris-Jerman, Gramedia.

[7] Hikam, AS. 1999. Demokrasi dan Civil Society. Jakarta: LP3ES.

[8] Halliday, M. A. K. 1993. "Language as Social Semiotic." Janet Maybin (Ed.) Language and Literacy in Social Practice: A Reader: Clevedon: Multilingual Matters, pp. 23-43.

[9] Voloshinov, N.N. 1993. "Language and Ideology." Janet Maybin (Ed.) Language and Literacy in Social Practice: A Reader: Clevedon: Multilingual Matters, pp. 44-57.

[10] Halliday, M.A.K. and Hasan, R. 1985. Language, Context And Text: Aspects Of Language In A Social-Semiotic Perspective. Victoria: Deakin University.

[11] Halliday, M.A.K. 1994. An Introduction to Functional Grammar $\left(2^{\text {nd }} E d\right.$.). New York, Edward Arnold.

[12] Lukin, A. (2013). Journalism, ideology and linguistics: The paradox of Chomsky's linguistic legacy and his 'propaganda model'. Journalism, 14(1), 96-110.

[13] Afroz, Sadia., Brennan, Michael, dan Greenstadt, Rachel. 2012. Detecting Hoaxes, Frauds, and Deception in Writing Style Online. 2012 IEEE Symposium on Security and Privacy. https://ieeexplore. ieee.org/stamp/stamp.jsp?arnumber=6234430. Diakses 12 Pebruari 2019 pukul 17.00 WITA
[14] Pinheiro, A., Cappeli, C. and Maciel, C. 2017. Designing Auditability in Social Networks to Prevent the Spread of False Information. IEEE Latin America Transactions, VOL. 15, No. 12, December 2017, pp. 2282-2289.

[15] Gelfert, Axel. 2018. Fake News: A Definition. Informal Logic, Vol. 38, No.1 (2018), pp. 84-117.

[16] Bhatt, Gaurav., Sharma, Aman., Sharma, Shivam., dan Nagpal, Angkush. 2017. On the Benefit of Combining Neural, Statistical and External Features for Fake News Identication. Cornell University Computation and Language. https://arxiv.org/pdf/1712.03935.pdf. Accessed on 12 February 2019 at 19.00 WITA.

[17] Wardle, Claire. 2016. 6 Types of Misinformation Circulated this Election Season. Columbia Journalism Review. Nov 18, 2016. https://www.cjr.org/tow_ center/6_types_election_fakenews.php Accessed on 21 Sept 2019.

[18] PEN America. 2017. FAKING NEWS Fraudulent News and the Fight for Truth. file:///D:/00PENELITIAN/2017-Faking-News11.2.pdf. Accessed on 21 Nov 2019.

[19] Rashkin, Hannah., Choi, Eunsol., Jang, Jin Yea,. 2017. Truth of Varying Shades: Analyzing Language in Fake News and Political Fact-Checking. Proceedings of the 2017 Conference on Empirical Methods in Natural Language Processing, pages 2931-2937 Copenhagen, Denmark, September 7-11, 2017. Association for Computational Linguistics.

[20] Yusra, Kamaludin. 2012. Language and Social Solidarity. Mataram, CERDAS Publication.

[21] Yusra, Kamaludin, dan Lestari, Yuni Budi. 2017. Teacher Strategies in Integrating Attitude, Knowledge and Skills in K-13 English Lessons: A Case Study of Islamic Boarding Schools in Lombok. Makalah diperesentasikan The Tenth Conference On Applied Linguistics And The Second English Language Teaching And Technology Conference November 22 - 23, 2017 Banana Inn Bandung.

[22] Yusra, Kamaludin, dan Lestari, Yuni Budi. 2018. Integrating Attitude, Knowledge and Skills in K-13 English Lesson Plans: Explorations into Teachers' Agentic Roles in Materials Development. Asian EFL Journal, 20 (3): 172-190.

[23] Farooq, G. 2017. Politics of Fake News: how WhatsApp became a potent propaganda tool in India. Media Watch, 9(1), 106-117.

[24] Hofstadter, R. 2012. The paranoid style in American politics. Vintage.

[25] Hocking, J. 2003. Counter-Terrorism and the Criminalisation of Politics: Australia's New Security Powers of Detention, Proscription and Control. Australian Journal of Politics \& History, 49(3), 355-371. 